\title{
Esportes nos confins da civilização: Mato Grosso, 1920-1930
}

Cleber Dias*

\section{RESUMO}

Analisando livros de viagem e de memorialistas, alguns documentos oficiais e jornais publicados no Mato Grosso, disponíveis nos acervos do Arquivo do Estado do Mato Grosso, da Biblioteca Nacional do Rio de Janeiro e do Arquivo do Exército, este artigo descreve e interpreta a história dos esportes no Mato Grosso na década de 1920, período que corresponde a um considerável processo de expansão social e geográfica dessas práticas na região. O desenvolvimento histórico do esporte no Mato Grosso, articulado a um nascente mercado de entretenimento de massas, esteve relacionado a transformaçôes mais amplas e estruturais que afetaram a região no período, tais como mudanças nas relaçôes de gênero, intensificação do associativismo civil e crescimento econômico e demográfico.

Palavras-chave: história; esporte; lazer; cultura; Mato Grosso.

\section{ABSTRACT}

Analyzing travel books and memoirs, a number of official documents and especially local newspapers, all available in the Mato Grosso State Archives, the National Library in Rio de Janeiro, and the Army Archive, this paper examines the history of sports in Mato Grosso in the 1920s, a period corresponding to a social and geographic expansion of these practices in the region. The historical development of the sport in Mato Grosso, articulated with a rising mass entertainment market, was linked to broader and structural changes affecting the region at the time, such as changes in gender relations, intensification of civil organizations, and economic and demographic growth.

Keywords: History; sports; leisure; culture; Mato Grosso.

\section{RESUMEN}

Analizando libros de viaje y de memorialistas, algunos documentos oficiales y periódicos locales, disponibles en los acervos del Archivo del Estado de Mato Grosso, de la Biblioteca

DOI - http://dx.doi.org/10.1590/2237-101X0183404

Artigo recebido em 20 de julho de 2016 e aprovado para publicação em 31 de agosto de 2016.

* Professor na Universidade Federal de Minas Gerais, Belo Horizonte - MG, Brasil.. E-mail: cleberdiasufmg@gmail.com.

Este estudo contou com apoio financeiro do CNPq. 
Nacional de Rio de Janeiro y del Archivo del Ejercito, este artículo describe e interpreta la historia de los deportes en Mato Grosso en la década de 1920, periodo que corresponde a un considerable proceso de expansión social y geográfica de estas prácticas en la región. El desarrollo histórico del deporte en Mato Grosso, articulado un naciente mercado de entretenimiento de masas, estuvo relacionado con transformaciones más amplias y estructurales que afectaron la región en el período, como mudanzas en las relaciones de género, intensificación del asociativismo civil y crecimiento económico y demográfico.

Palabras clave: história; deporte; ocio; cultura; Mato Grosso.

Analisando livros de viagem e de memorialistas, alguns documentos oficiais e sobretudo jornais publicados no Mato Grosso, disponíveis nos acervos do Arquivo do Estado do Mato Grosso, da Biblioteca Nacional do Rio de Janeiro e do Arquivo do Exército, este artigo analisa a história dos esportes no Mato Grosso na década de 1920, período que corresponde a um considerável processo de expansão social e geográfica dessas práticas na regiāo. A partir de 1920, aproximadamente, o desenvolvimento histórico dos esportes intensificou-se no Mato Grosso, depois dos seus registros iniciais nas duas primeiras décadas daquele século. ${ }^{1}$ As principais evidências nesse sentido são a diversificação de modalidades; a criação de jornais especializados ou a ampliação da atenção oferecida pela imprensa em geral ao assunto; a construção de estádios; a criação de ligas e federaçôes; o envolvimento crescente de órgãos governamentais; a ampliação do espectro geográfico onde essas atividades aconteciam e o envolvimento de grupos sociais mais heterogêneos, para além dos restritos círculos de homens das elites que o praticavam no início de maneira quase exclusiva.

Mato Grosso, que até 1978 abrangia também o atual Mato Grosso do Sul, é uma região que ocupa um lugar peculiar no imaginário brasileiro. Situado no extremo oeste do território nacional, nas fronteiras com a Bolívia e o Paraguai, Mato Grosso foi e é ainda representado como um lugar distante, isolado e atrasado. Em 1927, Luiz Amaral, registrando viagem que realizara até a regiáo, enfatizou bem a situação, ao classificar o Mato Grosso como uma das gatas borralheiras da federação, "o estado em que o resto do país tem como ficção geográfica", um "far-west", "região extra-mapa-múndi", um "sertão incognoscível", um "rincão deserto de ser humano e de civilizaçâo". ${ }^{2}$ De acordo com esta representaçâo típica, quaisquer elementos de progresso material ou simbólico estariam ausentes da regiáo. Mato Grosso, portanto, seria o lugar da falta de sofisticação dos comportamentos urbanos,

\footnotetext{
${ }^{1}$ DIAS, Cleber. Primórdios dos esportes em Mato Grosso, 1905-1919. Tempo, Niterói, no prelo.

2 AMARAL, Luiz. A mais linda viagem: um "raid" de vinte mil kilometros pelo interior brasileiro. São Paulo: Comp. Melhoramentos de S. Paulo, 1927, p. 11.
} 
marcado, em vez disso, por uma ruralidade arcaica e temporalmente imóvel, onde transformaçôes não chegam ou demoram muitíssimo a chegar; onde tudo que é tido por moderno lhe seria estranho.

Esses enquadramentos explicam parcialmente a ausência de pesquisas históricas sobre os esportes no Mato Grosso. Usualmente, o estudo histórico dos esportes esteve teoricamente associado a um cenário social de progresso, urbanização e modernidade, de tal maneira que a vinculação desta prática a uma regiấo como o Mato Grosso pareceria até uma contradição em termos. Este artigo pretende problematizar parte dessas premissas, ao mesmo tempo que tenta oferecer uma contribuição para superar essa lacuna historiográfica, pois o conhecimento sobre a história de regiôes cultural, econômica ou politicamente periféricas não pode ser uma suposição deduzida do que se sabe sobre a história dos centros hegemônicos. No Brasil, o florescimento de práticas esportivas ocorreu também em regióes pouco ou nada urbanizadas, às vezes bastante carentes de vestígios de processos modernizadores. Mesmo em algumas dessas situações, porém, os esportes foram regular e amplamente praticados, desde os meados da década de 1910, se não antes, servindo como veículos importantes para negociação de representaçóes sociais e identidades regionais. ${ }^{3}$ Foi precisamente este o caso do Mato Grosso.

Desde o fim da Guerra do Paraguai, o Mato Grosso experimentou um processo de desenvolvimento econômico e demográfico significativo. $\mathrm{O}$ desenvolvimento mais amplo do capitalismo internacional aumentou a disponibilidade de capitais na regiáo, induzindo o crescimento da demanda por matérias-primas agropastoris produzidas no Mato Grosso, bem como uma pequena diversificação produtiva. Junto com o aumento populacional, cujo cálculo total aumentou de 92 mil habitantes em 1890, para 240 mil em 1920, cresceram também ofertas de serviços urbanos e a receita financeira do Estado, que triplicou entre 1906 e 1918. Vários contemporâneos registaram com entusiasmo as mudanças estruturais que se processavam. Em 1919, Silva Simoens, que viajou do Rio de Janeiro até Cuiabá para representar o governo federal nas comemoraçóes do bicentenário da capital mato-grossense, ao passar por Corumbá, adjetivou-a de "ultracosmopolita", destacando positivamente o jardim público da cidade, "abundantemente iluminado a eletricidade", além da água canalizada, bons hotéis, fábricas de cerveja, gelo, cal e águas gasosas, "várias casas bancárias de certo vulto", ou ainda as ruas "largas", "calçadas", "perfeitamente alinhadas", "sem becos ou vielas". "O próprio desenvolvimento do esporte, identificável e crescentemente dinâmico desde meados da década de 1910, sugere uma imagem diferente daquela que táo caracteristicamente afeta o Mato Grosso.5

Por outro lado, em que pese todas essas transformaçóes, Mato Grosso continuava uma regiáo economicamente subdesenvolvida, com um mercado consumidor restrito, uma densi-

\footnotetext{
${ }^{3}$ DIAS, Cleber. Esporte e cidade: balanços e perspectivas. Tempo, Niterói, v. 17, n. 34, p. 33-44, jan./ jun. 2013.

${ }^{4}$ SILVA, Simoens da. Cartas Mattogrossenses. Rio de Janeiro: Imprensa Nacional, 1927, p. 27.

${ }^{5}$ DIAS, Cleber. Primórdios dos esportes em Mato Grosso, 1905-1919, op. cit.
} 
dade demográfica rarefeita, hábitos muitas vezes alheios aos novos dogmas comportamentais que se disseminavam internacionalmente e uma infraestrutura urbana que continuava frustrando expectativas de suas elites. As exportaçóes mato-grossenses de borracha e erva-mate, por exemplo, que aumentaram significativamente em princípios do século $\mathrm{XX}$, servindo como um dos principais elementos para o seu crescimento econômico, mesmo assim eram proporcionalmente pequenas quando comparadas aos volumes produzidos por outras regiōes. A erva-mate do Paraná ou a borracha do Amazonas e do Pará respondiam por parcelas nacionais de exportação muito maiores do que aquelas produzidas no Mato Grosso. ${ }^{6}$ Nativos e viajantes forasteiros que estiveram na região registraram as limitaçôes da infraestrutura urbana que ainda afetava várias cidades mato-grossenses entre as décadas de 1910 e 1920. Ao passar por Porto Esperança, cidade que servia de parada obrigatória para os que chegavam no Mato Grosso por trem ou por barco, o mesmo Silva Simoens já citado surpreendeu-se negativamente com as casas do local, incluindo-se o hotel: "meros barracóes de paredes e tetos de zinco ou barracas de madeira". Em Cuiabá, apesar do destaque ao "tráfego de automóveis e de carroças de toda sorte com regular frequência", surpreendeu-se com a falta de diversōes e também de hotéis, que lhe pareceram "espeluncas [...] sem a mínima higiene".7 Os próprios moradores de Cuiabá registraram a carência de diversóes em artigos nos jornais locais em que se queixavam sobre a vida monótona e sem alegria que levavam os habitantes do Mato Grosso. ${ }^{8}$

Nota-se, assim, uma estrutura social ambivalente. De um lado, cidades ou partes delas "ultracosmopolitas", com todos os progressos modernos disponíveis: a praça ajardinada, a eletricidade, a água encanada, o telégrafo, o cinema e os esportes. De outro lado, porém, uma ruralidade arcaica, com mais caminhos para estradas de boi do que estradas para carros, com uma infraestrutura urbana no mais das vezes pobre, com poucos confortos e opçôes de lazer. Esse tipo de ambiguidade bastante característica da vida social mato-grossense não constitui, todavia, uma peculiaridade. No Brasil de princípios do século XX, para onde quer que se olhasse ver-se-ia ambivalências, como concluiu Lilia Schwartz: "maxixe e lundu com música clássica, cordel com literatura acadêmica, transporte acelerado com o ritmo do lombo do burro, um país urbano ladeado pela realidade isolada dos sertóes". ${ }^{9}$ Mesmo cidades como o Rio de Janeiro, que foram objeto de um intenso esforço modernizador em

\footnotetext{
${ }^{6}$ BORGES, Fernando Tadeu de Miranda. Do extrativismo à pecuária: algumas observaçóes sobre a história econômica de Mato Grosso (1870 a 1930). Cuiabá: s/d, 1991.

7 SILVA, Simoens da. Cartas Mattogrossenses. Rio de Janeiro: Imprensa Nacional, 1927, respectivamente, p. 21 e 87.

${ }^{8}$ Ver Chroniqueta. O Pharol, Cuiabá, 15 dez. 1906, n. 71, p. 3; O Theatro. O Pharol, Cuiabá, 22 set. 1906, n. 59, p. 1; O theatro. O Pharol, Cuiabá, 27 nov. 1909, n. 225, p. 1; DELORME, Marion. Cartas a amiguinha. O Jornal, Cuiabá, 6 abr. 1922, n. 1, p. 3.

9 SCHWARCZ, Lilia Moritz. Introduçáo: as marcas do período. In: SCHWARCZ, Lilia Moritz (Coord.). História do Brasil nação: 1808-2010. (A abertura para o mundo, 1889-1930). Rio de Janeiro: Objetiva, 2012, p. 19-33. v. 3.
} 
princípios do século XX, não se veriam livres das diversas ambiguidades na sua estrutura e organização social, conciliando aspectos tidos como extremamente elegantes e civilizados, com outros, apontados como arcaicos e tradicionais. Foi precisamente neste ambiente que se desenvolveram os esportes no Mato Grosso.

Mais especificamente, o desenvolvimento histórico do esporte no Mato Grosso, notável, sobretudo, a partir de 1920, dar-se-ia em profunda articulação com transformaçóes mais amplas e estruturais que afetaram a regiáo no período, tais como mudanças nas relaçóes de gênero, intensificação do associativismo civil, ampliação do mercado de entretenimento de massas, além do crescimento econômico e demográfico. O estudo histórico dos esportes no Mato Grosso, uma prática teoricamente vinculada a um ideal de progresso, modernidade e sofisticação comportamental, em uma regiáo marcada por representaçóes de atraso e isolamento, além de permitir relativizar premissas ao redor desses estereótipos e convençôes, permite também questionar criticamente parte das conclusôes predominantes na historiografia brasileira especializada em esportes.

\section{Militares}

$\mathrm{Na}$ historiografia do esporte, o associativismo civil tem sido apontado como elemento histórico importante para a difusão desta prática, onde a fundação de clubes, ligas ou federaçôes aparece como dinâmica privilegiada desse processo. ${ }^{10}$ No entanto, ao lado deste aspecto, seguramente relevante, outros agentes desempenharam papel igualmente decisivo. As organizaçóes militares estão entre elas. ${ }^{11}$

Em princípios do século XX, depois de sucessivos resultados militares embaraçosos, como a Guerra do Paraguai ou de Canudos, a elite do Exército brasileiro se preocupava sobremaneira e não sem razóes com as fragilidades na defesa do país. Ao lado da falta de equipamentos, a preparação dos soldados era vista como motivo importante para tal situa-

${ }^{10}$ SZYMANSKI, Stefan. A Theory of the Evolution of Modern Sport. Journal of Sport History, v. 35, n. 1, p. 1-3, primavera 2008.

${ }^{11}$ MASON, Tony. The military, sport, and physical training. In: HOULIHAN, Barrie; GREEN, Mick (Eds.). Routledge Handbook os Sports Development. Nova York: Routledge, 2011, p. 42-50; MANGAN, A.; NDEE, Hamad S. Military Drill — rather more than 'Brief and Basic': English Elementary Schools and English Militarism. In: MANGAN, A. (Ed.). Militarism, Sport, Europe: war without weapons. Londres: Frank Cass, 2003, p. 67-99. No Brasil, ver CANCELLA, Karina. O esporte e as forças armadas na Primeira República: das atividades gymnasticas às participaçôes em eventos esportivos internacionais. Rio de Janeiro: Biblioteca do Exército, 2014. SILVA, Carlos Leonardo Bahiense; MELO, Victor Andrade de. Fabricando o soldado, forjando o cidadão: o doutor Eduardo Augusto Pereira de Abreu, a Guerra do Paraguai e a educação física no Brasil. História, Ciências, Saúde-Manguinhos, Rio de Janeiro, v. 18, n. 2, p. 337-353, 2011; HORTA, José Silvério Bahia. O hino, o sermão e a ordem do dia: regime autoritário e a educação no Brasil (1930-1945). 2. ed. Campinas: Autores Associados, 2012; CASTRO, Celso. Exército e nação: estudos sobre a história do Exército brasileiro. Rio de Janeiro: Editora FGV, 2012. 
ção. A Primeira Guerra Mundial e uma disposição beligerante aparentemente generalizada só reforçavam essas apreensôes. Como alternativa, sugeria-se adoção do alistamento militar obrigatório e a revisão dos mecanismos para formação de oficiais e treinamento de soldados. Reformas curriculares nas escolas de formação militar foram uma das medidas nesse sentido, especialmente diante da tradição bacharelesca e positivista que predominava até então. ${ }^{12}$

Vários militares formados neste novo contexto institucional, engajados já com a organização de treinamentos que enfatizavam habilidades propriamente marciais, oferecidos para o crescente número de recrutas que ingressavam agora compulsoriamente no Exército, acabaram desempenhando grande protagonismo na difusão de esportes em várias regiōes do Brasil. Primeiro, o esporte era cada vez mais assimilado como recurso para a preparação de soldados. Segundo, devido à característica mobilidade territorial da carreira militar, que frequentemente exigia transferências por diferentes regiōes do país, associada a uma respeitabilidade pública e a uma nova ideologia que prescrevia uma ativa participação social e política dos militares, a atuação desses grupos como veículos de intermediação para a difusão de esportes tornou-se privilegiada. Nas primeiras décadas do século XX, os militares talvez tenham sido um dos grupos mais ativos e preparados para disseminaçáo dos esportes — o que pode ser especialmente verdadeiro em regióes afastadas dos maiores centros metropolitanos. O protagonismo desempenhado por militares para o desenvolvimento e popularizaçáo de esportes no Mato Grosso ilustra bem a maneira como se dava essa dinâmica.

Em meados da década de 1920, por ocasiáo de uma marcha de resistência e velocidade entre Campo Grande e Aquidauana, que somava um trajeto de 145 quilômetros de distância, militares como os sargentos Jubal Coutinho e Danillo Paladini seriam celebrados na imprensa mato-grossense como "valentes", "distintos cavalheiros" e "apaixonados partidários da cultura física". Segundo notícia publicada no jornal Correio do Sul, de Campo Grande:

Encarando-a sob o seu verdadeiro aspecto e discorrendo com critério e clareza sobre a sua utilidade militar, mais uma vez nos convencemos das verdades sempre novas contidas neste velho aforismo: "mens sana in corpore sano" [...] Que os almofadinhas abandonem o carmim, o pó de arroz, os cremes e as infinidades de drogas com que se efeminizam dia a dia na vida ociosa das avenidas e sigam o exemplo desses dois jovens virilizados pelos salutares exercícios físicos, tornando-se homens fortes e capazes de se defenderem a si próprios e a pátria. ${ }^{13}$

Com efeito, vários outros militares estiveram envolvidos em diversas iniciativas esportivas em Mato Grosso nessa época. Desde 1917, militares do Exército mantinham equipes de futebol em Cuiabá com relativa importância para o cenário futebolístico da cidade:

\footnotetext{
${ }^{12}$ MACCANN, Frank D. Soldados da pátria: história do Exército brasileiro, 1889-1937. São Paulo: Companhia das Letras, 2007.

${ }^{13}$ Marcha de resistência e velocidade. Correio do Sul, Campo Grande, 8 jan. 1925, n. 623, p. 1.
} 


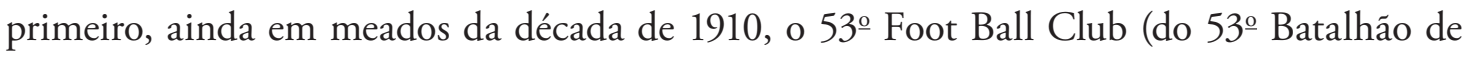
Caçadores); depois, já em princípios na década seguinte, o Pátria Foot-Ball (do 16oㅡ Batalhão de Caçadores).$^{14}$ Militares da cidade de Coimbra, Corumbá, Três Lagoas e Campo Grande também formariam suas próprias equipes esportivas, bem como organizariam eventos cívicos em que os esportes compunham parte da programação. ${ }^{15}$ Militares da Marinha e do Exército integraram a direção ou as equipes de ligas ou clubes de futebol, além de atuarem como árbitros de partidas. Por ocasiāo de datas cívicas comemorativas, unidades militares de Cuiabá promoviam eventos cuja programação incluía ginástica sueca, futebol, corridas e saltos. ${ }^{16}$ Em 1929, praças e oficiais da Marinha e do Exército em Corumbá, além de participarem de competiçôes contra equipes civis, criaram ainda seu próprio evento esportivo: a Taça Tuiuti Riachuelo. Nessa época, o campo do Ladário Atlético Clube, ligado ao pessoal da Marinha, já servia como uma das principais instalaçôes esportivas de Corumbá, sediando várias partidas de futebol.

A experiência prévia de muitos militares com a prática de esportes, bem como as exigências disciplinares que marcavam suas carreiras pareciam habilitá-los e legitimá-los para a função de veículos para edificação moral por meio da atividade física, bem de acordo com os valores e mentalidades que marcavam o período. Militares como Antonio Pejucan Cavalcante e A. Mauro Carvalho da Silva, que atuaram diversas vezes como juízes de partidas de futebol em Corumbá, foram positivamente destacados pela imprensa local por suas trajetórias anteriores como "conhecidos sportman [sic] no Rio de Janeiro". ${ }^{17}$ Da mesma forma, em Cuiabá, Diogo Clemente dos Santos, que organizou atividades esportivas em comemoraçôes cívicas, era representado, ainda em 1917, como "distinto oficial instrutor e apaixonado sportman". ${ }^{18}$ Ao longo dos anos 1920, o mesmo tipo de comentário elogioso continuaria sendo endereçado pela imprensa mato-grossense a vários militares que atuavam na regiáo. ${ }^{19}$

Outro bom exemplo do modo de atuação dos militares no processo de difusão esportiva é a trajetória do tenente Roberto Drummond. Nascido em Pernambuco em 1902, Drummond alistou-se voluntariamente no Exército em 1917. No ano seguinte, iniciou seus

\footnotetext{
${ }^{14}$ Para fontes sobre o 53ํㅡㄹ Foot Ball Club, ver Foot-ball. Republicano, Cuiabá, 26 jul. 1917, n. 65, p. 3; Foot-ball. O Matto-Grosso, Cuiabá, 22 abr. 1917, n. 1401, p. 3; Foot-ball. O Matto-Grosso, Cuiabá, 24 maio 1917, n. 1410, p. 2; 53 Foot Ball Club. O Matto-Grosso, Cuiabá, 17 jun. 1917, n. 1416, p. 2. Para fontes sobre o Pátria Foot-Ball, ver $A$ Cruz, Cuiabá, 4 jul. 1920, n. 473, p. 2; Football. O Jornal, Cuiabá, 14 out. 1922, n. 28, p. 3.

${ }^{15}$ Sport. Tribuna, Corumbá, 9 jan. 1929, n. 6444, p. 1; Sport. A Tribuna, Corumbá, 6 ago. 1927, n. 6047, p. 4; Pro hospital. A Tribuna, Corumbá, 28 abr. 1927; Futebol. A Notícia, Três Lagoas, 30 out. 1924, n. 1919, p. 2; Reunião da Associação T. E. A. Gazeta do Commercio, Três Lagoas, 24 jan. 1925, n. B243, p. 4; Esportes. Correio do Sul, Campo Grande, 6 set. 1925, n. 687, p. 2.

${ }^{16}$ A data de 24 de maio. O Matto-Grosso, Cuiabá, 27 maio 1917, n. 1411, p. 2; O Matto-Grosso, Cuiabá, 30 dez. 1917, n. 1463, p. 2.

${ }^{17}$ Sport. Tribuna, Corumbá, 9 maio 1928, n. 6256, p. 4.

${ }^{18}$ A data de 24 de maio. O Matto-Grosso, Cuiabá, 27 maio 1917, n. 1411, p. 2.

${ }^{19}$ Citam-se, por exemplo, Nelson Portillio e Lazaro Gomes Filho. Ver respectivamente Sport. Tribuna, Corumbá, 30 jul. 1921, n. 4771, p. 2 e Sport. Tribuna, Corumbá, 9 out. 1929, n. 6444, p. 4.
} 
estudos na Escola da Praia Vermelha, no Rio de Janeiro. Em 1921 foi designado para o Regimento de Artilharia Montada, em Itu, interior de São Paulo, logo destacando-se pelo "desvelo e competência na instrução dos conscritos do Regimento", contribuindo eficazmente "para o sensível progresso da instrução do grupo", conforme registrou seu capitão. Em Itu, encarregou-se ainda de dirigir os trabalhos no campo de instrução, especialmente a conservação de uma pista de obstáculos e a construção de um campo de tênis e outro de futebol, além de cuidar dos exercícios de tiro. Foi também nomeado membro da comissão esportiva do regimento, organizando ou participando de campeonatos de atletismo, esgrima, equitação e futebol, em locais como Itu, Lorena, Pirassununga, Rio de Janeiro ou São Paulo.

Muitos desses eventos esportivos extrapolaram os muros dos quartéis, envolvendo também associaçôes civis, amplificando, dessa maneira, os efeitos dessa atuação. Entre outras coisas, isto justificava os louvores públicos que seriam repetidas vezes endereçados ao tenente Drummond por seus superiores, pela "atividade entusiástica patente e capacidade incontestável da direção de torneios" ou "pela sua ardorosa e profícua atuação como encarregado dos desportos".

Em Mato Grosso a partir de 1924, mais especificamente no Regimento de Artilharia Mista, em Campo Grande, Drummond apenas continuou ativamente envolvido com os esportes. Organizou festas esportivas em Campo Grande, participou de jogos de futebol contra equipes civis em Três Lagoas, coordenou equipes esportivas em competiçôes em Aquidauana, ao mesmo tempo que se responsabilizou pela instrução militar de conscritos e oficiais dentro de sua unidade, o que muito provavelmente também já envolvia jogos esportivos, uma vez que os regulamentos de instrução física do Exército prescreviam essas atividades desde $1921 .{ }^{20}$

\section{Ligas, federações e associativismo civil}

Não obstante o ativo envolvimento de militares com a promoção e prática de esportes no período, a maioria das modalidades era promovida por associaçóes civis, cujas atividades principais radicavam-se acima de tudo no futebol. Com o tempo, porém, tais interesses expandiram-se para outros esportes, favorecendo uma diversificação de modalidades disponíveis. Um clube esportivo feminino, que organizava jogos de tênis, basquete, vôlei e pingue-pongue em Corumbá, foi criado em 1927 como espécie de desdobramento das açóes de um clube de futebol; numa iniciativa da Sra. Deolinda Barata (esposa de um comerciante ativamente envolvido com o Corumbaense Futebol Clube). Da mesma forma, outras moda-

\footnotetext{
${ }^{20}$ Para os dados relativos a Roberto Drummond, ver Arquivo Histórico do Exército. Fé de Ofício (II - 2037). Para informações sobre os regulamentos de instrução física do Exército de princípios dos anos 1920, ver DIAS, Cleber. Momentos iniciais da educação física em Goiás (1917-1929). Revista Brasileira de Educação Física e Esportes, São Paulo, v. 28, n. 1, p. 95-111, 2014.
} 
lidades desenvolviam-se como desdobramento do fortalecimento institucional de clubes de futebol. O mesmo Corumbaense Futebol Clube animou ainda a prática do tênis, adquiriu equipamentos de remo e anunciou o início de atividades de atletismo. ${ }^{21}$ Silva Freire logo celebrou a iniciativa nas páginas do jornal Tribuna. Segundo ele, "é assaz desvanecedora a notícia de que o Corumbaense F. C. iniciará dentro de pouco tempo a cultura atlética da nossa mocidade. Náo se restringindo ao foot-ball, que, parece, já deu os frutos que dele se poderiam esperar". ${ }^{22}$

Silva Freire, na verdade, preocupava-se com o uso "apropriado" de esportes para o fomento de virtudes morais, reforçando uma equação bastante disseminada desde entáo: a de que os esportes, praticados "adequadamente", isto é, de maneira racional e controlada, seriam capazes de aprimorar virtudes da alma, tanto quanto do corpo. A preocupaçáo de Freire justificava-se na premissa de que tal correlação não estava se realizando por completo, especialmente nos campos de futebol. Na visão dele, a capacidade de o futebol edificar e irradiar um modelo ideal de comportamento estaria esgotada, ou melhor, já teria dado os frutos que dele se poderiam esperar, conforme ele diz.

Não há atualmente, com exceção do boxe, sport capaz de despertar no povo sensação como o foot-ball; mas por isso mesmo ele toma aos indivíduos breack da razão, e os instintos primitivos, que residem no nosso subconsciente, brotam violentamente através da nossa frágil educação. E assim, o foot-ball deixa de ser um sport, que quer dizer brincadeira e diversão, para se tornar uma guerra medieval. E o fruto que se esperaria desse jogo, que é o desenvolvimento do espírito pelo desenvolvimento do corpo, se apresenta completamente transformado, pois em vez de se desenvolverem qualidades de homem, se desenvolvem qualidades de irracional. No atletismo, as cousas talvez não se farão assim, principalmente se os seus diretores tiverem sempre em mira que a cultura física só vale como subsidiária da cultura moral. ${ }^{23}$

Obviamente, a definição do que seria adequado ou apropriado pressupóe também a definiçấo do que seria, em contrapartida, inadequado ou inapropriado. Nesse caso, a racionalidade ou a irracionalidade, a apreciaçáo comedida e controlada, ou o envolvimento emotivamente passional seriam os elementos a definir a posição do esporte e dos modos de apreciá-lo ou praticá-lo nesta escala hierárquica.

Embora Freire não diga, suas opinióes poderiam estar apenas encobrindo uma tentativa de desacreditar publicamente os rumos institucionais que o futebol ia assumindo em Corumbá. No momento em que ele escrevia, havia se instalado uma disputa pelo controle do esporte na cidade entre a recém-criada Associaçáo Mato-Grossense de Atletismo e a mais

\footnotetext{
${ }^{21}$ PITÉ. Cartas. Tribuna, Corumbá, 16 abr. 1927, n. 5960, p. 4.

${ }^{22}$ FREIRE, Silva. O Athletismo no Corumbaense. Tribuna, Corumbá, 16 abr. 1927, n. 5960, p. 1.

${ }^{23}$ Ibidem, p. 1. Grifos no original.
} 
antiga Liga Mato-grossense de Esportes Atléticos, liderada, esta última, pelo Corumbaense Futebol Clube, com o qual Silva Freire tinha relaçôes. Além disso, como bem criticou um artigo anônimo no jornal Tribuna, "os defeitos que Silva Freire descobre no futebol atingirão amanhã o pingue-pongue, depois a regata, e por fim, dardos, corridas de resistência e velocidades, peso, etc., etc." ${ }^{24}$ De fato, a mesma estrutura de sentimentos do futebol criticado por Silva Freire já se manifestava em outras modalidades, como o boxe, que ele próprio identificara como o único esporte, além do futebol, capaz de causar "sensação no povo". $\mathrm{Ou}$ seja, ambas as modalidades, além de sua popularidade, compartilhavam também suas capacidades de despertar emoçóes acentuadas. Durante uma luta entre Romoaldo Ortiz e Luiz Henriques Oros, realizada no Circo Palma, em Ponta-Porâ, um jornal da cidade registrara o modo entusiasmado como espectadores relacionavam-se com o espetáculo. Segundo a notícia, "como sempre, a concorrência foi regular e houve partidarismo, portanto, entusiasmo". ${ }^{25}$

Nessa época, críticas ao que se chamava "partidarismo" já se faziam ouvir com persistência em outras instâncias esportivas, especialmente o futebol, o que nos permite inferir como teria sido o comportamento dos espectadores da luta entre Ortiz e Oros. Desde 1914, quando visivelmente inicia-se o processo de intensificação da prática do futebol em Mato Grosso, o "demasiado entusiasmo do povo" era já apontado por alguns críticos como responsável pelo esmorecimento da modalidade, embora provavelmente tenha exercido a influência contrária. Segundo registrava-se em tom crítico já: "um shoot, uma charge, uma queda era o bastante para uma vaia”. ${ }^{26}$ Ao longo da década de 1920, comportamentos como este não apenas continuariam se manifestando, como ganhariam ímpeto e regularidade. Tornaram-se mais ou menos frequentes referências a "invasão do povo no campo" ou a "jogadores descorteses, acostumados a presentear, em pleno ground, os juízes com descomposturas de baixo caláo". ${ }^{27}$

Uma das maneiras para tentar impor de modo mais eficiente uma regulação ao comportamento de jogadores foi o fortalecimento e ampliação das instituiçóes que controlavam os esportes. Os clubes já existiam desde antes. Todavia, iniciou-se também nessa época a busca por uma coordenação institucional maior e mais eficiente entre eles. Desde meados da década de 1910, cogitava-se criar uma liga de futebol em Cuiabá, o que só seria realizado, de fato, em princípios da década seguinte, com a fundação da Liga Mato-grossense de Desportos Atléticos em 1922, que reunia os três principais times de futebol da cidade: Tiradentes, Tupi e Comercial. Leônidas Pereira Mendes, engenheiro civil, vereador e diretor da Repartição e Obras Públicas do Estado, foi apontado como principal patrono da ideia, que era celebrada como importante recurso para o "fortalecimento da raça mato-grossense". ${ }^{28}$ Iniciativa seme-

\footnotetext{
${ }^{24}$ O Atletismo para certos atletas de hoje... Tribuna, Corumbá, 18 abr. 1927, n. 5961, p. 4.

${ }^{25}$ Box. O Progresso, Ponta Porã, 13 fev. 1927, n. 260, p. 1.

${ }^{26}$ DIAS, Cleber. Primórdios dos esportes em Mato Grosso, 1905-1919, op. cit.

${ }^{27}$ Football. O Jornal, Cuiabá, 23 set. 1922, n. 25, p. 6.

${ }^{28}$ Desportos. O Jornal, Cuiabá, 6 jul. 1922, n. 14, p. 3.
} 
lhante parece ter tido lugar em Corumbá em 1923, quando quatro equipes de futebol da cidade (Corumbaense, Riachuelo, Ladarense e Comércio) uniram-se para criar a Liga Mato-grossense de Esporte Atlético. Uma das iniciativas mais enfatizadas pela Liga de Corumbá foi a determinação de critérios para escolha dos árbitros. Segundo ficou decidido, cada clube indicaria quatro pessoas, cujos nomes seriam submetidos a uma votação secreta. Apenas àqueles que obtivessem 3/4 do total de votos poderiam atuar como árbitros. A preocupaçáo com o controle rigoroso sobre os árbitros visava disciplinar os jogadores, mas também os torcedores, que deveriam se acostumar ao estrito cumprimento das regras. ${ }^{29} \mathrm{~A}$ preocupaçáo com a arbitragem dos jogos de futebol foi se tornando uma questáo crescentemente valorizada, provavelmente em reação aos conflitos e atos de indisciplina de jogadores e espectadores, que também foram aumentando no período. Conforme registrara um jornal de Corumbá:

Um bom juiz é a garantia de uma boa partida. A presença em campo de um juiz conhecedor de regras, sensato e equilibrado, e de cuja idoneidade moral náo se possa duvidar, traz para os jogadores e assistentes uma confiança absoluta que perdoa até o erro a que está sujeito todo ser humano. ${ }^{30}$

Interessante notar como ambas as instituiçôes, de Corumbá e Cuiabá, além de contemporâneas, adotaram nomes quase idênticos, retratando a si mesmas como representantes do esporte mato-grossense em geral, e não apenas das respectivas cidades onde estavam sediadas, em particular. Embora Cuiabá fosse a capital do Estado, o que agregava prestígio à sua vida social, as elites de Corumbá concentravam considerável poderio econômico, o que também lhes infligia a pretensão de pioneirismo e centralidade sobre a vida cultural de Mato Grosso. Em 1929, quando se discutia as possibilidades de construção de um estádio de futebol em Corumbá, tais pretensóes revelaram-se na tentativa de justificar a importância do empreendimento, uma vez que esportistas corumbaenses viam a si mesmos como líderes e epicentros de um processo de difusão regional de esportes. Segundo registrou artigo de um jornal local: "atingimos aqui, completamente isolados do resto do país, o máximo possível em desenvolvimento e técnica esportivos e depois irradiamos para o resto do Estado o nosso progresso". ${ }^{31}$

Embora Cuiabá e Corumbá experimentassem uma vida esportiva aparentemente mais intensa que outras cidades mato-grossenses, é totalmente discutível a percepção de que essas cidades irradiassem seus progressos para outras partes do estado. Na segunda metade dos anos 1920, ligas ou federaçôes também foram criadas em Três Lagoas, Campo Grande e Ponta-Porã, sem relação explícita com os acontecimentos de Corumbá ou Cuiabá. A Asso-

\footnotetext{
${ }^{29}$ Sport. Tribuna, Corumbá, 29 abr. 1929, n. 6532, p. 4.

${ }^{30}$ Sport. Tribuna, Corumbá, 15 abr. 1929, n. 6520, p. 4.

${ }^{31}$ Sport. Tribuna, Corumbá, 1o out. 1929, n. 6657, p. 4.
} 
ciação Três-lagoenses de Atletismo, por exemplo, criada em 1927, promovia regularmente competiçóes e torneios entre equipes esportivas da cidade, além de organizar frequentemente partidas contra equipes de São Paulo, o que agregava ares de cosmopolitismo a esses eventos e a até a própria cidade. Corumbá, por outro lado, só receberia equipes paulistas para partidas de futebol em meados da década de $1930 .^{32}$

Criada em 1912 pela empreiteira responsável pela construção da Estrada de Ferro Noroeste do Brasil como ponto de apoio para as obras, Três Lagoas logo passaria a ser vista como cidade possuidora de uma vida agitada e adiantada, com teatros, hotéis, padarias e drogarias. Em 1927, Luiz Amaral, nos registros da viagem que fizera a Mato Grosso, quando visitou Três Lagoas, destacou o que lhe pareciam ser "aspectos admiráveis", atribuindo adjetivos elogiosos à cidade: "ampla, muito bem traçada, ruas muito largas e muito retas, com duas ordens de postes para iluminação elétrica, abundantíssima. Comércio intenso, população operosa”. ${ }^{33}$

Igualmente importante, enquanto entusiastas do esporte em Corumbá discutiam formas de viabilizar a construção de um estádio, Três Lagoas já poderia comemorar o terceiro ou quarto aniversário de construçáo do estádio local, com 300 metros quadrados, todo cercado por tábuas de dois metros de altura, à margem da estrada de ferro, dotado de serviço telefônico e contendo campo de futebol gramado, além de espaços para tênis, pingue-pongue e patinaçáo. $\mathrm{O}$ acesso ao estádio realizava-se por uma avenida arborizada de 15 metros de largura, "destinada ao corso de automóveis", como registrava orgulhosamente um jornal da cidade. Ao redor do campo de futebol, iluminado à luz elétrica, um "artístico" gradil. Havia ainda um galpão e um apartamento em forma de chalé para a diretoria e os convidados ilustres, além da previsão de construção de um bar e de um coreto que seriam alugados a comerciantes interessados. ${ }^{34}$

Antes também de Corumbá e Cuiabá, em 1929 inaugurou-se um estádio em Campo Grande, com a presença de Aníbal de Toledo, presidente do estado à época. O estádio ocupava área de 18 mil metros quadrados, toda cercada com folhas de zinco, com um campo de futebol de tamanho máximo $(118 \times 91 \mathrm{~m})$, cercado com grade de madeira, pavilhão de arquibancadas para 500 pessoas, bilheteria e coreto de música. ${ }^{35} \mathrm{Em}$ fins da década de 1920, Campo Grande tornara-se já um cento comercial importante, concentrando grande parte das movimentaçóes econômicas do Mato Grosso. Já em 1920, a população da cidade superara em número a de Corumbá, tradicional entreposto comercial mato-grossense. Enquanto Campo Grande contava pouco mais de 21 mil habitantes nesta data, Corumbá contava pouco menos de 20 mil. ${ }^{36}$ Vários cronistas registraram o progresso que afetava a ci-

\footnotetext{
${ }^{32}$ BAEZ, Renato, Corumbá, futebol e copa: história de todas as copas do mundo, Corumbá. s. 1., s. n., 1966. ${ }^{33}$ AMARAL, Luiz. A mais linda viagem: um "raid" de vinte mil kilometros pelo interior brasileiro, op. cit, p. 11.

${ }^{34}$ A nossa praça de esportes. Gazeta do Commercio, Três Lagoas, 16 jan. 1927, n. 296, p. 1.

${ }^{35}$ Sociedade Sportiva Campograndense. A Cruz, Cuiabá, 27 out. 1929, n. 897, p. 2.

${ }^{36}$ QUEIROZ, Paulo Roberto Cimó. Uma ferrovia entre dois mundos: a E. F. Noroeste do Brasil na primeira metade do século 20. Bauru/Campo Grande: Edusc/Ed. UFMS, 2004, p. 364.
} 
dade. Em 1914, Eduardo Machado, apresentando a cidade para o Álbum gráfico do Estado do Mato Grosso, iniciativa que pretendia divulgar as vantagens e os progressos de Mato Grosso, registrara as rápidas transformaçóes que a atingiam:

Há pouco mais de dois anos [1912] era um vilarejo insignificante, contando apenas cento e tantas casas, em sua maioria de pau-a-pique, e uns 1.200 habitantes: atualmente possui cerca de 500 fogos, notando-se já um certo gosto nas construçóes, e contando com uma populaçáo fixa de nunca menos de 5.000 almas. $^{37}$

Apesar do contexto propagandístico para o qual se endereçavam essas palavras, o que certamente lhes fazia encerrar um caráter sempre elogioso, é certo que uma onda de transformaçôes atingiu não apenas Campo Grande, mas várias cidades do sul do Mato Grosso (no que é hoje o Mato Grosso do Sul), em razão, sobretudo, da chegada ou da proximidade com a estrada de ferro, o que só iria se intensificar com o tempo. Em 1929, Zé Jeremia, em relato sobre uma viagem entre Maracaju e Campo Grande, justamente por ocasião da inauguração do estádio de Campo Grande, registrara que a cidade já apresentava feiçóes de centro populoso, com cheiro de gasolina, tintas, vernizes e perfumes caros. ${ }^{38} \mathrm{~A}$ difusão da prática de esportes era apenas mais um elemento a reforçar percepçóes sobre a modernidade de Campo Grande. Nessa época, além do futebol, campeonatos de ciclismo, boxe e atletismo também já se organizavam na cidade. ${ }^{39}$

Em Corumbá e Cuiabá, todavia, apesar do notável desenvolvimento esportivo que lhes afetava ao longo da década de 1920, a construção de um estádio, logo tomado como prova do progresso atlético de uma cidade, era ainda uma ambição sem realização prática. Em Cuiabá, a comemoraçáo do bicentenário da cidade, em 1920, deflagrou um projeto de melhoramentos urbanos que previa a construção de um campo com coreto, arquibancada, pavilhão para hipódromo e espaços para futebol e tênis. ${ }^{40}$ Todavia, não se tratava exatamente de um estádio para esportes, mas sim de uma grande instalação para usos diversos, incluindo os esportivos, embora não se restringindo a eles.

Em Corumbá, desde os meados daquela década, campos de futebol começaram a se multiplicar: Campo do Carvalho, da Fortaleza, da Peixarada, da Cervejaria, da Barranqueira, do Dezessete, do Beira Mar e da Esplanada. No entanto, o único local utilizado para jogos de futebol que mais se aproximava da ideia de um estádio, isto é, uma construção arquitetônica especialmente edificada para a prática de esportes, era o campo do Comércio Esporte Clube (fundado em 1921 e ligado aos comerciantes da cidade), que contava com

\footnotetext{
${ }^{37}$ Apud QUEIROZ, Paulo Roberto Cimó. Uma ferrovia entre dois mundos: a E. F. Noroeste do Brasil na primeira metade do século 20, op. cit, p. 324.

${ }^{38}$ JEREMIA, Zé. Cincoeta quilômetros á hora. A Campanha, Campo Grande, 1o set. 1929, n. 8, p. 3-4.

${ }^{39}$ Campeonato de cyclimo. Correio do Sul, Campo Grande, 28 jun. 1928, n. 1466, p. 1.

${ }^{40}$ Bi-centenário de Matto-Grosso. A Cruz, Cuiabá, 4 ago. 1918, n. 388, p. 3.
} 
arquibancadas de madeira, o que não por acaso lhe qualificou como principal local para realização de campeonatos em Corumbá.$^{41} \mathrm{O}$ campo, porém, não parecia contar com muros, o que era um aspecto importante para a caracterizaçáo de um estádio propriamente dito. Além da possibilidade da cobrança de ingressos, a construção de muros ao redor dos campos permitia um controle mais efetivo de quem poderia ou náo integrar-se ao espetáculo como espectador.

Além de motivaçôes simbólicas, radicadas no desejo de ostentação pública de refinamento comportamental, esforços para construçâo de estádios de futebol pareciam se justificar também no desejo de fortalecer os mecanismos de disciplinamento de jogadores e espectadores. Em 1922, a atuação do Delegado de Polícia de Cuiabá, que a fim de evitar a "invasão do povo", percorria "sem parar" as linhas laterais do Campo do Ourique, tradicional local de festividades públicas e partidas de futebol da cidade, já não se mostrava suficiente:

Os nossos 'goals' não estão convenientemente aparelhados, não dispóe da necessária rede, como exige o jogo, dando lugar a um expediente menos digno, empregado por alguns jogadores do quadro rubro-negro, que, afim de desnortear o 'keeper' adversário, aliciam dezenas de meninos vagabundos, para, durante o jogo, estacionarem na linha do 'goal', em algazarra desabrida, em vais infindáveis, em gritaria infernal, não só atrapalhando a açâo do 'keeper', como ainda empurrando a bola para dentro do 'ground', quando a mesma já devia ser considerada fora de campo. ${ }^{42}$

Em 1926, artigo do jornal A Capital, de Cuiabá, apontou novamente para a falta de instalaçôes esportivas adequadas para o futebol como uma das principais causas dos frequentes episódios de tumulto e invasão de campos que se testemunhavam na cidade à época. Como alternativa, sugeria-se uma articulação coordenada entre os diferentes clubes de futebol da cidade para construção de um estádio, o que deveria também ser amparado pelo poder público.

Os acontecimentos verificados domingo último no campo do Sport Clube Cuiabano, quando ali disputaram uma partida amistosa as primeiras esquadras deste clube com a do Tupi F.C., vieram demonstrar a necessidade imperiosa de possuir Cuiabá um campo devidamente para esses 'matchs'. Efetivamente não se pode admitir que tais encontros continuem a ser levados a efeito nas praças onde até então tem sido feitos. Sem que possa ser evitado, o campo é constantemente invadido pelos exaltados partidários dos clubes disputantes, ao menor incidente que se verifique entre os jogadores. E vai dali o presenciarmos as cenas deprimentes do último encontro. Uma questão que poderia ser resolvida entre os 'captains' e o juiz do jogo, teve logo a intervenção dos torcedores 'valentes', que invadindo o 'ground' estabeleceram

\footnotetext{
${ }^{41}$ BAEZ, Renato, Corumbá, futebol e copa: história de todas as copas do mundo, op. cit.

${ }^{42}$ Football. O Jornal, Cuiabá, 23 set. 1922, n. 25, p. 6.
} 
um verdadeiro 'charivari', interrompendo, destarte, a continuação da partida. E nem se diga que a responsabilidade desse incidente caiba a este ou aquele. Cabe aos exaltados de ambos os clubes. Estas cenas, que aliás quase sempre se dão quando os disputantes são um clube do Porto e outro do 1 Distrito, a nosso ver teria que forçosamente desaparecer com a adoçáo de um campo onde os jogadores ficassem completamente separados do público. E nesta cidade, onde os entusiastas do 'foot-ball' já formam um grupo bastante numeroso, não seria difícil a realização dessa nossa ideia. ${ }^{43}$

O desdobramento dos acontecimentos contrariaria os prognósticos do cronista anônimo de que seria fácil a articulação das associações esportivas de Cuiabá visando à construção de um estádio. De todo modo, é certo que o papel desempenhado por essas instituiçóes para o desenvolvimento esportivo do esporte na regiáo mostrou-se importante. Por meio delas, organizaram-se jogos e campeonatos, propagandearam-se as vantagens da prática esportiva, organizaram-se pequenos grupos de pressáo política para obtenção de modestas vantagens para clubes e suas instalaçôes, além de terem servido de veículo às rivalidades que foram combustíveis importantes para o crescente envolvimento popular com tais práticas (especialmente o futebol).

\section{Políticas de gênero e comercialização do lazer}

Desde princípios do século XX, parecia crescer em Mato Grosso o número de clubes, associaçóes recreativas ou mesmo outras instalaçóes para o lazer, como hotéis, teatros e cinemas. Esses locais integravam parte importante dos rituais de sociabilidade e diversão das elites. Frequentemente, esses espaços também serviam de diferentes formas a propósitos esportivos: hotéis eram locais para reuniôes de clubes, cinemas promoviam exibições de filmes em favor de agremiaçóes esportivas ou eram utilizados para fundação de clubes esportivos, exibição de filmes de esportes ou realizaçáo de lutas de boxe.

No caso específico das lutas de boxe, parecia mesmo haver um complexo e extenso circuito empresarial em funcionamento na década de 1920, espraiando-se do Paraguai até São Paulo, atravessando várias cidades mato-grossenses e envolvendo empresários, treinadores, atletas, espectadores, redatores de jornais e proprietários de casas comerciais. Nessa época, revanches de lutas realizadas anteriormente em Assunção ou Conceição do Paraguai foram organizadas em cidades do Mato Grosso. Figuras como Mathias Canela, antes lutador, passaram a atuar como empresários, agenciando a participaçáo de estrangeiros, especialmente paraguaios, em turnês de boxe em cidades do Mato Grosso ou mesmo de outros estados,

${ }^{43}$ Pebolismo. A Capital, Cuyabá, 8 fev. 1926, n. 58, p. 4. 
especialmente São Paulo. ${ }^{44} \mathrm{~A}$ imprensa era peça-chave do processo, apresentando lutadores, destacando suas qualidades, glorificando seus feitos e legitimando suas credibilidades esportivas. Jornais cediam espaço para a promoção desses eventos, claramente tentando se aproveitar comercialmente da ocasião. Alimentando expectativas ao redor das lutas, os jornais serviam como intermediários para o lançamento de desafios ou eventuais trocas de ofensas entre lutadores ou treinadores. Uma luta entre os paraguaios Isidro Flores e Ignacio Flores, por exemplo, iniciou-se com a publicação de cartas de provocaçáo recíproca nas páginas do jornal O Progresso. Numa delas, em espanhol, o empresário de Ignacio Flores dizia: "em resposta ao desafio feito pelo aficionado senhor Isidro Flores, e em representação do meu pupilo, [ele, Ignacio Flores] aceita as proposiçóes do dito match". ${ }^{45}$ Em Corumbá, Antonio Artusa também se valeu das páginas de um jornal local para responder ao desafio lançado a todos os amadores e profissionais da cidade pelo confiante Waldomiro Lobo, que se autointitulava campeão de Minas Gerais. ${ }^{46}$

Associaçôes recreativas mais genéricas também promoviam diferentes práticas esportivas como parte de suas programaçóes. Em Três Lagoas, o saláo do Clube Concórdia era palco de partidas de pingue-pongue, descritas pela imprensa local como "jogos verdadeiramente deslumbrantes". ${ }^{47}$ Em Corumbá, no mesmo sentido, jogos de pingue-pongue integravam parte importante de reunióes promovidas entre diferentes clubes da cidade. Essas partidas seriam "ansiosamente esperadas pela sociedade elegante", com assistências "enormes", onde destacavam-se os licores, os cordiais brindes, além da presença dos membros de maior destaque social da cidade. ${ }^{48}$ Apenas reforçando o glamour desses eventos, ao mesmo tempo que tentavam explorá-los como ocasião publicitária, casas comerciais frequentemente ofereciam "valiosas e artísticas prendas", "serviços de porcelana", "vidros de finíssimos extratos", "ricos estojos de perfumaria", "finíssimas carteiras de couro da Rússia". ${ }^{49}$ Práticas esportivas, em suma, serviam como ocasião para a exibição pública e para o encontro entre diferentes redes de convívio das elites, ampliando seus respectivos espectros de interação, além de dar oportunidade a canais para propaganda ou mesmo comercializaçáo de produtos e serviços oferecidos por negociantes locais.

Campeonatos esportivos também favoreciam encontros entre grupos de diferentes cidades. Nessa época, jovens de Três Lagoas, Miranda, Campo Grande, Ponta-Porã e Aquidauana às vezes se deslocavam com o propósito específico de realizar encontros esportivos em outras cidades..$^{50}$ Para dimensionar a importância que atividades como essa pareciam

44 Ignacio Flores. O Progresso, Ponta-Porã, 18 set. 1927, n. 291, p. 3; Roberto Durand. O Progresso, Ponta Porã, 15 out. 1927, n. 295, p. 2; O Progresso, Ponta-Porã, 12 out. 1927, n. 294, p. 1.

${ }^{45}$ Box. O Progresso, Ponta-Porã, 25 set. 1927, n. 292, p. 2. Tradução minha.

${ }^{46}$ ARTUSA, Antonio. A Pedidos. Tribuna, Corumbá, 7 maio 1928, n. 6255, p. 4.

${ }^{47}$ Pingue pongue. Gazeta do Commercio, Três Lagoas, 10 maio 1925, n. 217, p. 6.

${ }^{48}$ No "alvi rubro". Tribuna, Corumbá, 8 abr. 1927, n. 5955, p. 1.

${ }^{49}$ Corumbaense F. C. Tribuna, Corumbá, 22 abr. 1929, n. 6526, p. 4.

${ }^{50}$ Sport. Tribuna, Corumbá, 1ำ mar. 1928, n. 6205, p. 4. 
desempenhar para os envolvidos, deve-se considerar o esforço que deslocamentos desse tipo exigiam na época. Uma viagem de barco entre Corumbá e Montevidéu, no Uruguai, poderia levar de 20 a 40 dias, dependendo da embarcação, das condiçôes de navegação e da experiência dos tripulantes. Além da demora, o viajante precisava ainda lidar com frequências e periodicidades relativamente baixas na oferta de linhas para viagens de passageiros. Embora houvesse embarcaçôes dotadas de algum conforto e até de certo luxo, a maioria era bastante precária.

Por terra a viagem não era melhor..$^{51}$ Até 1916 não havia nada que se pudesse chamar de estradas em Mato Grosso. Apenas trilhas e caminhos carroçáveis. Em 1923, contabilizava-se 20 caminhos, que juntos somavam mais de 3.500 quilômetros de extensão, que permitiam tráfego de veículos de carga. Todavia, o modo predominante de deslocamento por terra seguia ainda mais arcaico. Caminhos carroçáveis destinados a bois de carga somavam, na mesma época, quase 5.500 quilômetros de extensão. Todas essas possibilidades de deslocamento por terra tinham condiçôes de tráfego sofríveis. Segundo a sumária descrição de um viajante que trafegou pelo caminho que ligava São Miguel a Cuiabá em 1927: "desce-se, entra-se e roda-se aos trambolhóes". ${ }^{52}$ Em 1929, descrevendo viagem entre Maracaju e Campo Grande, a bordo de um Oldsmobile, o popular veículo da General Motors, Zé Jeremia também nos legou impressão bastante vívida das más condiçôes das "estradas de rodagem" mato-grossenses:

A estrada não é boa. Os largos "pneus" dos caminhóes que arfam sob a carga de mate, em sua quase totalidade, esburacam-na e a crivam de ressaltos e covancas. Não obstante as molas dóceis dos coxins em que nos assentamos, somos obrigados a atos de acrobacia, a uma dança que os mais modernos "dancings" e "cabarets" não conhecem. ${ }^{53}$

Era preciso boa dose de motivação para enfrentar às vezes longas horas desses deslocamentos a fim de participar de encontros esportivos. Como vimos, porém, para além do esporte em si, que era importante, com certeza, esses eventos serviam também de ocasião para o encontro, e talvez mais importante, para o encontro entre pessoas de diferentes sexos, o que poderia torná-los especialmente atraente aos jovens. O esporte atuava como pretexto conveniente para ocupação do espaço público, o que poderia ser especialmente importante para grupos até então cerceados em suas possibilidades nesse sentido, como o eram as mulheres de estrato social mais elevado.

Ao longo de boa parte do século XX, homens olharam com suspeitas e formularam restriçôes para a prática de exercícios por mulheres, especialmente aqueles mais extenuantes ou

\footnotetext{
${ }^{51}$ OLIVEIRA, Vitor Wagner Neto de. Nas águas do prata: os trabalhadores da rota fluvial entre Buenos Aires e Corumbá (1910-1930). Campinas: Ed. da Unicamp, 2009.

${ }^{52}$ AMARAL, Luiz. A mais linda viagem: um "raid" de vinte mil kilometros pelo interior brasileiro, op. cit, p. 84.

53 JEREMIA, Zé. Cincoeta quilômetros á hora, op. cit, p. 3.
} 
vigorosos. Eventualmente, apenas atividades fisicamente moderadas seriam recomendadas para o sexo "frágil" e "belo", o que tornava algumas modalidades esportivas mais recomendadas que outras. A ginástica, a natação, o vôlei ou o tênis estiveram entre as modalidades mais usualmente recomendadas, enquanto futebol, boxe, turfe ou remo estiveram entre as mais desencorajadas, às vezes proibidas. ${ }^{54}$ Ideias assim também circularam em Mato Grosso. Um artigo de 1917, publicado no jornal católico A Cruz, em Cuiabá, ironizou prescrições para a prática de atividades esportivas por mulheres. Segundo dizia:

Nos grandes centros modernos a questão de sport apaixona também o mundo feminino. No Brasil, e, sobretudo, entre nós as sportwomen são em número limitadíssimo, o que não é para deplorar, antes pelo contrário. Nos Estados Unidos do Norte, os sports fazem parte da educação das moças que na frivolidade do tennis ou nas brutalidades das corridas, lutas a box, adquirem uns jeitos de masculinização pouco recomendáveis.

O professor Dudley Sargent, da Universidade de Harvard, no decurso duma conferência às suas alunas, espirituosamente as aconselhou a regressar aos sports femininos, cultivados desde tempos imemoráveis. Eis as suas palavras, onde o humour yankee deliciosamente se reflete:

"Se quereis encontrar um sport racional, higiênico, que dê ao vosso corpo força e beleza entregai-vos aos trabalhos domésticos. Para fortificar os músculos e alargar o peito, nada há melhor que subir e descer escadas. Trabalhar, levantando as duas mãos produz o mesmo efeito sobre o busto. Para dar flexibilidade aos ombros, o manejo da vassoura é insuperável. Podemos acrescentar-lhe o transporte sucessivo de baldes com água. Amassar farinha dá-nos ao antebraço uma firmeza e uma redondeza que não se obtém por outro meio; e lavar a roupa durante uma hora equivale a jogar o tennis toda a semana".

Quantas donas de casa fazem todos os dias sport sem o saber! ${ }^{55}$

Além de julgar deploráveis situaçóes em que o esporte era mais amplamente praticado por mulheres, como lhe parecia ser o caso dos Estados Unidos, o artigo também revelava que mulheres se envolviam com tais práticas em Mato Grosso, mesmo que "em número limitadíssimo". De fato, desde meados da década de 1910 registrava-se já uma dinâmica de envolvimento feminino com esportes na região. Nessa época, comentando o crescimento do movimento esportivo em Cuiabá, perceptível no surgimento de vários clubes de futebol e na criação de um clube de patinação, artigo do jornal $O$ Debate citava as intençóes de

\footnotetext{
${ }^{4}$ SCHPUN, Mônica Raisa. Beleza em jogo: cultura física e comportamento em São Paulo nos anos 20. São Paulo: Boitempo Editorial/Editora Senac, 1999; GOELLNER, Silvana Vilodre. Bela, maternal e feminina: imagens da mulher na revista educação phisica. Ijui: Unijuí, 2003. FRANZINI, Fábio. Futebol é "coisa para macho"?: pequeno esboço para uma história das mulheres no país do futebol. Revista Brasileira de História, v. 25, n. 50, p. 315-328, 2005; MELO, Victor Andrade de. Mulheres em movimento: a presença feminina nos primórdios do esporte na cidade do Rio de Janeiro (até 1910). Revista Brasileira de História, v. 27, n. 54, p. 127-152, 2007.

${ }_{55}$ Magnífico sport feminino. A Cruz, Cuiabá, 22 abr. 1917, n. 324, p. 2. Grifos no original.
} 
fundação de uma "sociedade feminina", cujo fim seria "exercitar as suas associadas nos belíssimos jogos de law-tennis e cricket", o que parece não ter acontecido, todavia. Por fim, acrescentava ainda que Madame Hessleins (esposa do vice-cônsul da Alemanha) e outras senhoras e senhoritas cuiabanas estariam à frente deste "movimento feminino", inspiradas, porém, em ideias de um tal Dr. Landys, apontado, afinal, como "o principal fator desse movimento desportivo". ${ }^{6}$

Se na década de 1910 a participação esportiva feminina era mais uma ambição do que um fato, na década seguinte as mulheres de Mato Grosso seguramente adentraram nas arenas esportivas, em que pese as muitas restriçôes que ainda pesavam sobre elas. Não é claro se homens e mulheres chegaram a jogar entre si. Mas é certo, porém, que ambos os sexos compartilhavam os mesmos espaços de diferentes formas.

Marion Delorme, possivelmente um pseudônimo em homenagem à famosa personagem da vida social parisiense imortalizada em óperas e peças teatrais, legou-nos um excelente relato sobre uma dessas formas de interaçáo entre os sexos promovida pelos esportes. Reproduzindo ou simulando reproduzir uma carta, ela narra sua experiência durante partida de futebol entre o Tupy e o Tiradentes, numa tarde de domingo em Cuiabá de 1922. Acompanhada por uma amiga, Delorme não apenas frequenta o campo de futebol, como admite nutrir "simpatias bem pronunciadas" por dois dos principais times da cidade à época: justamente o Tupy e o Tiradentes. Naquela tarde, em particular, movida por um costume que ela própria classificou de "excêntrico", escolhera torcer para o Tupy, ou melhor, contra o Tiradentes. Delorme, desde a época em que visitara ou vivera no Rio de Janeiro, tinha por costume torcer contra o time de futebol que lhe parecia mais civilizado e elegante. Nesse caso, o que a fizera perceber o Tiradentes nesses termos foi a presença de um jovem entusiasta daquele time que lhe parecia incorporar tais atributos.

$\mathrm{Na}$ verdade, para Delorme, como vai relevando sua carta, tão ou mais importante que o jogo em si, eram as possibilidades de encontro com o outro sexo que o esporte descortinava. Mais que goals, driblings ou shoots, interessava-lhe possibilidades de contato com um jovem do sexo oposto, visto como elegante e civilizado.

Quando o jogo se tornou perigoso para a parte a que eu era contrária, como que negligentemente dei uns shootsinhos nos seus pés, e disse aparentando grande interesse pelo mesmo:

- É goal! É goal feito...

O meu vizinho, entretanto, dedicava mais atenção ao jogo que... a mim.

E com isso é que eu não estava de acordo.

Quando, pelo contrário, o keeper do Tupy fez uma defesa, eu, entâo, dando com um dos braços no rapaz, disse à Zilah [amiga que acompanha Delorme]:

— Distinto! Bravos ao Bouret [goleiro do Tupy]!

\footnotetext{
${ }^{56}$ Varias noticias. O Debate, Cuiabá, 15 maio 1914, n. 771, p. 3. Grifos no original.
} 
Ele, sentindo primeiro o contato "casual" dos meus pés e depois de um dos meus braços, movimentou, por traz dos óculos, os seus olhinhos brilhantes, volveu o seu rosto, pousou um olhar em mim, e um sorriso, o primeiro, muito brando, quase imperceptível, perpassou, por instantes, em seus coralinos lábios...

Depois, as situaçôes do jogo atraíram lhe novamente a atenção; não me desanimei; e em seguida, interessando-me vivamente pelo match, dei-lhe uma pequena alfinetada enquanto gritava à Zilah:

- Hands! Foi hands! E o juiz não puniu!

O rapaz volveu-me os olhos, e entâo falou me com maior carinho, sorriu-me mais demoradamente e dirigiu a palavra:

- Perdão, senhorita, tal não houve...

Foi início de uma palestra longa e adorável.

Quando o jogo terminou, estávamos muito amiguinhos, havíamos simpatizado mutuamente; ele deu-me um delicado cartáo com o seu nome e endereço, com a promessa, para mim agradabilíssima, de que nos veríamos dentro em breve, a que eu retribuí com um olhar...

Sei que estás doidinha para saber quem é.

Mas eu não te digo, não, por enquanto.

Não faltarei ao match do dia 21 , que vai ser sensacional. ${ }^{57}$

Nesse caso, Delorme ocupava o lugar de espectadora, o que lhe envolvia até vivamente com a partida, como ela própria confessa, sem a permitir jogar propriamente, todavia. No entanto, excluindo-se o futebol e algumas outras modalidades de fato interditadas ao jogo feminino, mulheres náo apenas assistiam aos esportes, mas inteiravam-se ativamente e com destaque na sua prática. Por ocasiáo de um campeonato de pingue-pongue em Corumbá, a imprensa local chegou a classificar um quadro feminino como estando em "estado de perfeição", capaz de enfrentar "com brilho" qualquer equipe da cidade. ${ }^{58}$ Nessa época, ao menos em Cuiabá e Corumbá, mulheres também se engajaram, regularmente, parece, na prática do tênis, do basquete e do vôlei. ${ }^{59}$ Em todos os casos, depois das partidas, jogando ou náo entre si os sexos, eram comuns "animadas danças", com a presença tanto de homens quanto de mulheres, quase sempre prolongadas até o raiar do sol. ${ }^{60}$

Se não se encontraram dentro dos campos e quadras esportivas, tais ocasióes festivas ofereceram pretexto adequado para o compartilhamento de espaços de sociabilidade entre os sexos, pois era usual, quase regra mesmo, que se seguissem outros eventos sociais depois

\footnotetext{
${ }^{57}$ DELORME, Marion. Cartas de amiguinhas. O Jornal, Cuiabá, 20 abr. 1922, n. 3, p. 2.

${ }^{58}$ Sport. Tribuna, Corumbá, 21 mar. 1928, n. 6222, p. 1.

${ }^{59}$ Sport. Tribuna, Corumbá, 17 abr. 1929, n. 6522, p. 4; Tennis. O Democrata, Cuiabá, 31 ago. 1929, n. 691, p. 4; Tennis. O Democrata, Cuiabá, 14 set. 1929, n. 702, p. 4; Jogos interessantes. O Democrata, Cuiabá, 13 jul. 1930, n. 936, p. 4.

${ }^{60}$ Uma festa agradável. Tribuna, Corumbá, 22 abr. 1929, n. 6526, p. 4.
} 
dos jogos, especialmente bailes dançantes. Assim, mais que simples encontros, acontecimentos esportivos também proporcionavam outras formas mais estreitas de interação. Não apenas em Mato Grosso, mas em várias partes, políticas cotidianas de gênero concorreram na estruturação de novos usos sociais do corpo, notadamente os esportes e todas as redes de sociabilidade a ele associadas, tais como as próprias danças praticadas em bailes que se seguiam aos jogos e competiçóes.

\section{Consideraçóes finais}

O desenvolvimento histórico de esportes no Mato Grosso, em princípios do século XX, esteve articulado a transformaçóes mais amplas que afetaram a regiáo anos antes, desde o quartel final do século XIX. ${ }^{61}$ De maneira análoga, transformaçôes que se processaram nos esportes a partir do início da década de 1920 estão também ligadas a mudanças estruturais que começaram a se processar mais de uma década antes, a partir do final da primeira década do século XX. A partir de 1908, com a inauguraçáo do primeiro trecho da Estrada de Ferro Noroeste do Brasil, que ligava Bauru, no interior de Sáo Paulo, a Itapura, também em São Paulo, mas já próximo da fronteira do Mato Grosso, a órbita de influência social, cultural e econômica do Mato Grosso passaria cada vez mais a gravitar em direção a São Paulo. Em vez de uma economia em grande medida voltada para o comércio internacional com a regiáo do Prata através da navegação do rio Paraguai e seus afluentes, nota-se, dessa época em diante, um progressivo deslocamento econômico do comércio mato-grossense em direção a São Paulo através das linhas da Estrada de Ferro Noroeste do Brasil.

No campo esportivo, a nova situação parece ter estimulado uma vinculação social e simbólica paulatinamente maior do Mato Grosso com São Paulo. Nessa época, jornais mato-grossenses começaram a publicar, ainda que eventualmente, notícias sobre acontecimentos esportivos de Sáo Paulo, especialmente os que envolviam equipes ou atletas de outros países. ${ }^{62}$ Equipes mato-grossenses de futebol começaram a contar com jogadores outrora participantes de equipes de São Paulo. Dudu, por exemplo, incorporado ao plantel do Internacional Futebol Clube, de Cuiabá, notabilizava-se por fazer prodígios ao enfrentar o inimigo, varando todo o ground como uma flecha, "com incrível agilidade", além de ser "um foot-baller experimentado que já fez parte de teams em São Paulo" — fazia questão de sublinhar a imprensa local. ${ }^{63}$ Gustavo Kullman, igualmente, fundador e atacante do mesmo Internacional Futebol Clube, fora aluno da Escola Normal Caetano de Campos,

\footnotetext{
${ }^{61}$ DIAS, Cleber. Primórdios dos esportes em Mato Grosso, 1905-1919, op. cit.

${ }^{62}$ J. B. de Mesquita. Notas paulistas. O Commercio, Cuiabá, 17 nov. 1910, n. 38, p. 1.

${ }^{63}$ Foot-ball. O Debate, Cuiabá, 25 nov. 1913, n. 635, p. 2. Para outro exemplo sobre o destaque atribuído à presença de jogadores do Rio de Janeiro e sobretudo de Sáo Paulo em partidas no Mato Grosso, ver Foot-ball. Republicano, Cuiabá, 26 jul. 1917, n. 65, p. 3.
} 
em Sáo Paulo, onde protestantes norte-americanos incluíram jogos esportivos ao menos desde 1906 como parte de uma reforma curricular, mudara-se para o Mato Grosso com a missão de dirigir o grupo escolar do 2o distrito de Cuiabá. ${ }^{64}$ Mesmo fora dos campos, figuras como João da Costa Marques, secretário de agricultura em Cuiabá, anteriormente envolvido com o Paulistano Futebol Clube, fora aclamado presidente honorário do Cuiabá Futebol Clube. ${ }^{65}$

Mas o estreitamento de laços de diferentes tipos com São Paulo não implicou quaisquer dissoluçôes de sólidas relaçôes com todo o universo platino. Mesmo do ponto de vista material ou econômico, a construçáo de novas vias de comunicação por ferrovia não substituiu por completo a navegação fluvial, se não as complementou em muitos aspectos. Do mesmo modo, o crescimento demográfico e comercial de Campo Grande, notável, de fato, não inibiu de todo o papel de entreposto desempenhado por Corumbá. ${ }^{66}$

Também nos campos esportivos, não há uma substituição de relações ou influências vindas do Prata em favor de outras vindas de outras partes. Fora um uruguaio o primeiro a ser apontado como responsável por introduzir o futebol em Corumbá, incentivando partidas envolvendo sobretudo paraguaios e uruguaios. Para aquisiçáo dos primeiros equipamentos esportivos, os pioneiros do futebol e do remo em Mato Grosso costumavam destinar-se ao Paraguai em primeiro lugar. ${ }^{67}$

A intensificação do desenvolvimento esportivo a partir da década de 1920, bem como a diversificaçấo de modalidades praticadas, mantiveram-se bastante relacionadas com o contexto platino. No boxe, por exemplo, que chegou a ser tida como a única prática mato-grossense capaz de rivalizar em popularidade com o futebol nessa época, lutadores, treinadores e empresários do Paraguai mostraram-se importantes para o desenvolvimento desta modalidade. No futebol, do mesmo modo, equipes de futebol mato-grossenses atravessavam a fronteira para disputar partidas contra equipes paraguaias, além de contar com jogadores bolivianos, paraguaios e uruguaios. Equipes de destaque como o Riachuelo, de Corumbá, vencedoras de muitas partidas e campeonatos da época, contariam, entre alguns de seus jogadores, com atletas como "Uruguaio" e Gonzalez. ${ }^{68}$

\footnotetext{
${ }^{64}$ O Commercio, Cuiabá, 15 ago. 1911, n. 150, p. 1-2. A passagem de Gustavo Kullman pela Escola Normal de São Paulo é apontada por SILVA, Elizabeth Poubel e. O Florescer de uma Cultura Escolar no Ensino Público Matogrossense. In: VIDAL, Diana Gonçalves (Org.). Grupos escolares: cultura escolar primária e escolarização da infância no Brasil (1893-1971). Campinas, SP: Mercado das Letras, 2006, p. 215-232. O papel dos norte-americanos na Escola Normal de São Paulo desde 1896, bem como a introduçấo de jogos esportivos ali, é reconstituída por GUEDES, Claudia. 'Changing the cultural landscape': English engineers, American missionaries, and the YMCA bring sports to Brazil — the 1870s to 1930s. International Journal of the History of Sport, v. 28, n. 17, p. 2594-2608, dez. 2011.

${ }^{65}$ Dr. Joâo da Costa Marques. O Debate, Cuiabá, 15 nov. 1913, n. 628, p. 1.

${ }^{66}$ QUEIROZ, Paulo Roberto Cimó. Uma ferrovia entre dois mundos: a E. F. Noroeste do Brasil na primeira metade do século 20, op. cit., p. 358-366.

${ }^{67}$ DIAS, Cleber. Primórdios dos esportes em Mato Grosso, 1905-1919, op. cit.

${ }^{68}$ Sport. A Tribuna, Corumbá, 17 ago. 1927, n. 6055, p. 1.
} 
De todo modo, ligando-se material e simbolicamente a um amplo circuito de trocas e deslocamentos, o desenvolvimento histórico do esporte no Mato Grosso, articulado a um nascente mercado de entretenimento de massas, sugere uma imagem bastante diferente daquela que tão caracteristicamente afeta a região, geralmente associando-a ao isolamento e ao atraso cultural. Na verdade, Mato Grosso, como o demonstra outros estudos sobre a região, bem como o seu desenvolvimento esportivo, esteve profundamente envolvido nas tramas globais que afetavam simultaneamente várias regiōes naquela época.

Fontes e referências bibliográficas

\section{Fontes}

A Campanha, Campo Grande, 1929.

A Capital, Cuiabá, 1926.

A Cruz, Cuiabá, 1917, 1918 e 1929,

A Luz, Cuiabá, 1924.

A Notícia, Três Lagoas, 1924.

AMARAL, Luiz. A mais linda viagem: um "raid" de vinte mil kilometros pelo interior brasileiro. São Paulo: Comp. Melhoramentos de S. Paulo, 1927, p. 11.

Arquivo Histórico do Exército (Rio de Janeiro), Fé de Ofício (II - 20-37).

Correio do Sul, Campo Grande, 1925 e 1928.

Correio do Sul, Campo Grande, 1925.

Gazeta do Commercio, Três Lagoas, 1925-1927.

O Commercio, Cuiabá, 1910 e 1911.

O Debate, Cuiabá, 1913-1914.

O Democrata, Cuiabá, 1929-1930.

O Jornal, Cuiabá, 1922.

O Matto Grosso, Cuiabá, 1917 e 1928.

O Pharol, Cuiabá, 1906, 1909 e 1925.

O Progresso, Ponta Porã, 1927.

Republicano, Cuiabá, 1917.

SILVA, Simoens da. Cartas Mattogrossenses. Rio de Janeiro: Imprensa Nacional, 1927, p. 27. Tribuna, Corumbá, 1921, 1927-1929. 


\section{Bibliografia}

BAEZ, Renato, Corumbá, futebol e copa: história de todas as copas do mundo, Corumbá. s. 1, s. n, 1966.

BORGES, Fernando Tadeu de Miranda. Do extrativismo à pecuária: algumas observaçóes sobre a história econômica de Mato Grosso (1870 a 1930). Cuiabá: s/d, 1991.

CANCELLA, Karina. O esporte e as forças armadas na Primeira República: das atividades gymnasticas às participaçóes em eventos esportivos internacionais. Rio de Janeiro: Biblioteca do Exército, 2014.

CASTRO, Celso. Exército e nação: estudos sobre a história do Exército brasileiro. Rio de Janeiro: Editora FGV, 2012.

DIAS, Cleber. Esporte e cidade: balanços e perspectivas. Tempo, Niterói, v. 17, n. 34, p. 3344, jan./ jun. 2013.

. Momentos iniciais da educação física em Goiás (1917-1929). Revista Brasileira de Educação Física e Esportes, Sáo Paulo, v. 28, n. 1, p. 95-111, 2014.

. Primórdios dos esportes em Mato Grosso, 1905-1919. Tempo, Niterói, no prelo.

FRANZINI, Fábio. Futebol é "coisa para macho"?: pequeno esboço para uma história das mulheres no país do futebol. Revista Brasileira de História, v. 25, n. 50, p. 315-328, 2005.

GOELLNER, Silvana Vilodre. Bela, maternal e feminina: imagens da mulher na revista educação phisica. Ijui: Unijuí, 2003.

GUEDES, Claudia. 'Changing the cultural landscape': English engineers, American missionaries, and the YMCA bring sports to Brazil - the 1870s to 1930s. International Journal of the History of Sport, v. 28, n. 17, p. 2594-2608, dez. 2011.

HORTA, José Silvério Bahia. O hino, o sermão e a ordem do dia: regime autoritário e a educação no Brasil (1930-1945). 2. ed. Campinas: Autores Associados, 2012.

MACCANN, Frank D. Soldados da pátria: história do Exército brasileiro, 1889-1937. São Paulo: Companhia das Letras, 2007.

MANGAN, A.; NDEE, Hamad S. Military Drill — rather more than 'Brief and Basic': English Elementary Schools and English Militarism. In: MANGAN, A. (Ed.). Militarism, Sport, Europe: war without weapons. Londres: Frank Cass, 2003, p. 67-99.

MASON, Tony. The military, sport, and physical training. In: HOULIHAN, Barrie; GREEN, Mick (Eds.). Routledge Handbook os Sports Development. Nova York: Routledge, 2011, p. 42-50.

MELO, Victor Andrade de. Mulheres em movimento: a presença feminina nos primórdios do esporte na cidade do Rio de Janeiro (até 1910). Revista Brasileira de História, v. 27, n. 54, p. 127-152, 2007. 
OLIVEIRA, Vitor Wagner Neto de. Nas águas do prata: os trabalhadores da rota fluvial entre Buenos Aires e Corumbá (1910-1930). Campinas: Ed. da Unicamp, 2009.

QUEIROZ, Paulo Roberto Cimó. Uma ferrovia entre dois mundos: a E. F. Noroeste do Brasil na primeira metade do século 20. Bauru/Campo Grande: Edusc/Ed. UFMS, 2004.

SCHPUN, Mônica Raisa. Beleza em jogo: cultura física e comportamento em São Paulo nos anos 20. São Paulo: Boitempo Editorial/Editora Senac, 1999.

SCHWARCZ, Lilia Moritz. Introdução: as marcas do período. In: SCHWARCZ, Lilia Moritz (Coord.). História do Brasil nação: 1808-2010. (A abertura para o mundo, 18891930). Rio de Janeiro: Objetiva, 2012, p. 19-33. v. 3

SILVA, Carlos Leonardo Bahiense; MELO, Victor Andrade de. Fabricando o soldado, forjando o cidadão: o doutor Eduardo Augusto Pereira de Abreu, a Guerra do Paraguai e a educação física no Brasil. História, Ciências, Saúde-Manguinhos, Rio de Janeiro, v. 18, n. 2, p. 337-353, 2011.

SILVA, Elizabeth Poubel e. O florescer de uma cultura escolar no ensino público matogrossense. In: VIDAL, Daiana Gonçalves (Org.). Grupos escolares: cultura escolar primária e escolarização da infância no Brasil (1893-1971). Campinas, SP: Mercado das Letras, 2006, p. 215-232.

SZYMANSKI, Stefan. A Theory of the Evolution of Modern Sport. Journal of Sport History, v. 35, n. 1, p. 1-3, primavera 2008. 